\title{
ANALISIS DEBIT LIMPASAN DRAINASE AKIBAT PENGARUH PERUBAHAN TATA GUNA LAHAN DI DAERAH KOTA SURABAYA BARAT
}

\author{
Alifia Faradina ${ }^{1}$, Indradi Wijatmiko ${ }^{2}$, Yatnanta Padma Devia ${ }^{2}$, M. Ruslin Anwar ${ }^{2}$ \\ ${ }^{1}$ Mahasiswa / Program Studi Sarjana Teknik Sipil Fakultas Teknik / Universitas Brawijaya \\ ${ }^{2}$ Dosen / Jurusan Teknik Sipil Fakultas Teknik / Universitas Brawijaya \\ Korespondensi: aliifia.2105@ymail.com
}

\begin{abstract}
The drainage area of the secondary drainage system of the Gunungsari often occurs inundation or flood during rain. This is due to land use change, which was originally a water catchment area transformed into a densely populated area that resulted in disruption of soil absorption so that runoff becomes bigger. The analysis used in this thesis includes hydrological analysis, land use analysis, domestic discharge analysis, cumulative discharge analysis and hydraulics analysis. The hydrological analysis calculated the rainfall at return period of 2, 5, and 10 year with the Pearson Log distribution III, discharge calculation of the plan with the return period by means of the rational method and the method of coefficient value of land use $(C)$ the land is then divided by the area of each sub das. The analysis of domestic waste was calculated from the total population prediction in the future and the water needs of the population. The cumulative discharge was total from domestic discharge and flood discharge of the return period of 2, 5, and 10 years. Hydraulic analysis was calculated to know the existing capacity of channel. The changing of land use were represented by average land use value ( $\left.C_{\text {average }}\right)$, which the value are 0,732; 0,725 and 0,747 for the year 2002; 2007 and 2017 respectively. Based on the results of flood discharge planning analysis, cumulative discharge in return periods of 10 years and hydraulic analysis, the flooding occurred at Darmo Indah channel (segment 5-2) by comparing capacity discharge $2,49 \mathrm{~m}^{3} / \mathrm{s}$ and cumulative discharge $4,360 \mathrm{~m}^{3} / \mathrm{s}$, Darmo Harapan channel (segment 4-5) by comparing capacity discharge $2,90 \mathrm{~m}^{3} / \mathrm{s}$ and cumulative discharge 4,496 $\mathrm{m}^{3} / \mathrm{s}$. Darmo Satelit channel (segment 7-8) by comparing capacity drainage 4,08 $\mathrm{m}^{3} / \mathrm{s}$ and cumulative discharge 4,586 $\mathrm{m}^{3} / \mathrm{s}$ and Simo Gunung channel (segment 18-19) by comparing capacity drainage and cumulative discharge $1,31 \mathrm{~m}^{3} / \mathrm{s}$ and $2,648 \mathrm{~m}^{3} / \mathrm{s}$. The capacity of existing secondary channels is not able to accommodate cumulative water discharge over the next 10 years. Therefore, the solution to overcome the flooding is by substituting existing channel box culvert. On the other had, another way to prevent flooding are maintenance and cleaning of solid waste and sedimention regularly.
\end{abstract}

Keywords: Analysis, Debit, Land Use, Gunungsari

\section{PENDAHULUAN}

Kota Surabaya merupakan Ibukota Provinsi Jawa Timur yang menjadi pusat kegiatan pemerintahan, ekonomi, politik, sosial budaya dan kegiatan lainnya. Laju pertumbuhan penduduk kota Surabaya berkembang dengan pesat sehingga kebutuhan lahan pemukiman juga meningkat. Hal ini menyebabkan peningkatan perubahan tata guna lahan dan mengurangi daerah resapan air hujan, sehingga menyebabkan banjir di beberapa daerah di Surabaya. Salah satu kawasan kota Surabaya yang sering terjadi banjir adalah kawasan Surabaya Barat. Surabaya Barat memiliki sistem drainase yaitu Sistem Drainase Gunungsari. Dalam sistem drainase tersebut memiliki saluran primer yaitu saluran primer Gunungsari (Gambar 1).

Saluran primer ini menampung debit banjir dan debit air buangan penduduk dari saluran sekunder yang dilayaninya antara lain saluran sekunder Simo Gunung, Simo Mulyo Barat, Simo Mulyo, Darmo Satelit, dan Darmo Indah. Saluran tersebut sering terjadi genangan atau banjir pada saat hujan. Hal ini dikarenakan adanya perubahan tata guna lahan, yang 
awalnya merupakan daerah resapan air berubah menjadi daerah padat pemukiman.

Adanya perubahan fungsi lahan, maka masalah yang akan timbul adalah semakin meningkatnya aliran permukaan [1]. Pada akhirnya kondisi inilah yang menyebabkan timbulnya genangan di beberapa lokasi karena debit limpasan yang ada sudah tidak dapat lagi tertampung oleh kapasitas saluran [2].

Berdasarkan uraian permasalahan diatas, maka dapat dirumuskan permasalahan yang akan dibahas yaitu perubahan tataguna lahan di Surabaya Barat tahun 2002 sampai 2017 untuk rencana tata ruang tahun 2030 , merancang debit banjir perode ulang 2, 5, 10 tahun, kapasitas eksisting saluran saat ini mampukah menampung debit banjir yang terjadi, solusi yang tepat untuk upaya penanggulangan perubahan tata guna lahan yang terjadi di kota Surabaya. Batasan masalah yang diberikan ialah daerah yang dianalisis hanya daerah limpasan drainase Kota Surabaya Barat, mengevaluasi tingkat penyalahgunaan tata guna lahan, debit banjir rencana yang digunakan hanya debit limpasan, tidak memperhitungkan rencana anggaran biaya pada saluran ini, tidak memperhitungkan sedimentasi, tidak mendesain ulang dimensi saluran pada analisis system drainase Gunungsari.

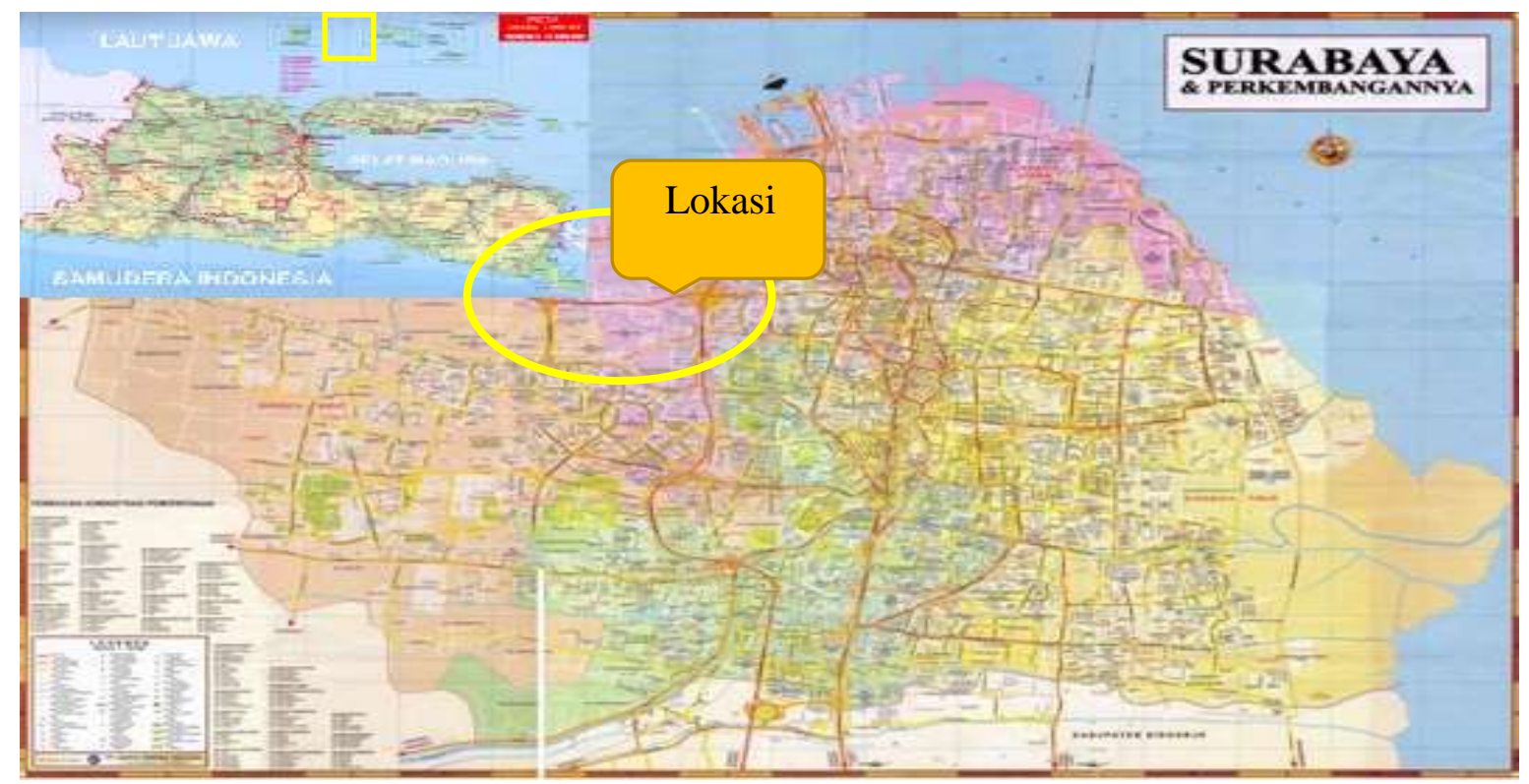

Gambar 1. Lokasi Studi

\section{METODOLOGI PENELITIAN}

Langkah atau metode yang dilakukan pada analisis pengaruh perubahan tataguna lahan terhadap debit limpasan drainase di kota Surabaya Barat yaitu persiapan, idenifikasi masalah, studi literature, pengumpulan data, analisis data, kesimpulan dan saran. Diagram alir penelitian disajikan pada Gambar 2.

\section{HASIL DAN PEMBAHASAN 3.1 Analisis Hidrologi}

Langkah awal yang dilakukan untuk perencanaan sistem drainase yaitu melakukan analisis yang bertujuan untuk mengetahui debit banjir yang dapat ditampung dan dialirkan oleh saluran.

\section{a. Perhitungan Curah Hujan Wilayah}

Perhitungan curah hujan wilayah ini bertujuan untuk mendapatkan curah hujan wilayah pada masing-masing stasiun hujan pada kawasan yang ditinjau. Pada perhitungan ini metode yang digunakan yaitu metode Poligon Thiessen, karena penyebaran stasiun hujan pada DTA yang ditinjau tidak merata. Ada dua stasiun yang berpengaruh yaitu stasiun hujan Gunungsari dan Banyu Urip. Hasil perhitungan curah hujan wilayah dapat dilihat pada Tabel 2. 


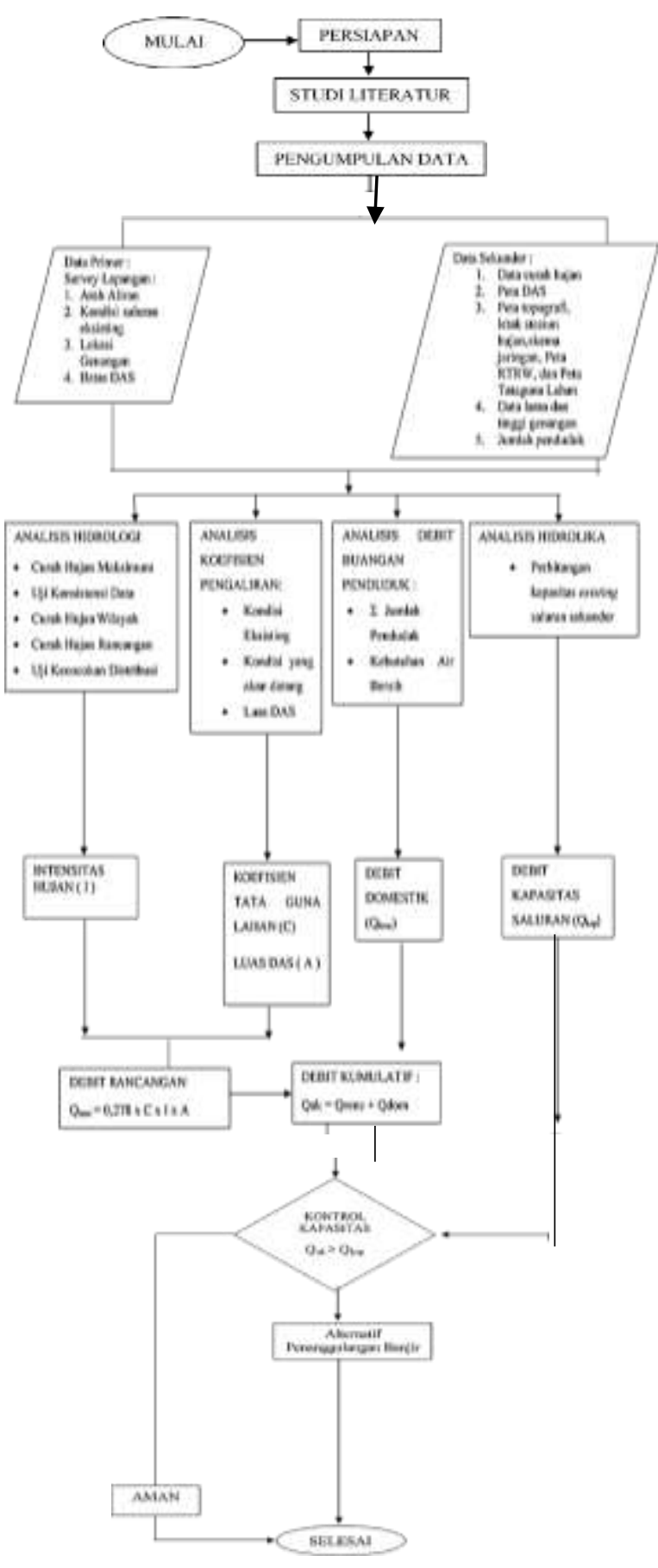

Gambar 2. Diagram Alir

\section{b. Perhitungan Curah Hujan Rancangan}

Untuk menentukan metode distribusi yang akan digunakan untuk menghitung curah hujan rancangan, sebelumnya dilakukan perhitungan parameter dasar statistik [3][4].

- Nilai Rata-rata (Mean)

$$
\bar{X}=\frac{\sum X}{n}=\frac{839,791}{10}=83,979
$$

- Perhitungan Standar Deviasi

$$
\begin{aligned}
S & =\sqrt{\frac{\sum\left(X_{i}-\bar{X}\right)^{2}}{n-1}} \\
& =\sqrt{\frac{4197,392}{9}}=21,5958
\end{aligned}
$$

- Perhitungan Nilai Koefisien Skewness $\left(\mathrm{C}_{\mathrm{s}}\right)$

$$
\begin{aligned}
C s & =\frac{n}{(n-1) \times(n-2) \times S^{3}} \times \sum_{i=1}^{n}\left(X_{i}-\bar{X}\right)^{3} \\
& =1,165
\end{aligned}
$$

\begin{tabular}{|c|c|c|c|c|}
\hline No & Distribusi & $\begin{array}{c}\text { Persyaratan } \\
{[4]} \\
\end{array}$ & $\begin{array}{c}\text { Hasil } \\
\text { Perhitungan }\end{array}$ & Keterangan \\
\hline \multirow{2}{*}{1} & \multirow{2}{*}{ Normal } & $\mathrm{Cs}=0$ & 1,16 & \multirow{2}{*}{$\begin{array}{c}\text { Tidak } \\
\text { Diterima }\end{array}$} \\
\hline & & $\mathrm{Ck}=3$ & 5,26 & \\
\hline \multirow{3}{*}{2} & \multirow{3}{*}{$\begin{array}{c}\text { Log } \\
\text { Normal }\end{array}$} & $\mathrm{Cs}=\mathrm{Cv}^{3}+3 \mathrm{Cv}$ & 0,79 & \multirow{3}{*}{$\begin{array}{c}\text { Tidak } \\
\text { Diterima }\end{array}$} \\
\hline & & $\mathrm{Ck}=\mathrm{Cv}^{8}+$ & & \\
\hline & & $\begin{array}{c}6 C v^{6}+15 C v^{4} \\
+16 C v^{2}+3 \\
\end{array}$ & 4,13 & \\
\hline \multirow{2}{*}{3} & \multirow{2}{*}{ Gumbel } & $\mathrm{Cs}=1,14$ & 1,16 & \multirow{2}{*}{$\begin{array}{c}\text { Tidak } \\
\text { Diterima }\end{array}$} \\
\hline & & $\mathrm{Ck}=5,4$ & 5,26 & \\
\hline 4 & $\begin{array}{c}\log \\
\text { pearson } \\
\text { III }\end{array}$ & $\begin{array}{c}\text { Selain dari } \\
\text { nilai } \\
\text { diatas/flexibel }\end{array}$ & & Diterima \\
\hline
\end{tabular}

- Perhitungan Nilai Koefisien Kurtosis $\left(\mathrm{C}_{\mathrm{k}}\right)$

$$
\begin{aligned}
C k & =\frac{n^{2}}{(n-1) \times(n-2) \times(n-3) \times\left(S^{4}\right)} \times \sum_{i=1}^{n}\left(X_{i}-\bar{X}\right)^{4} \\
& =5,262
\end{aligned}
$$

Tabel 1. Perhitungan Curah Hujan Wilayah

Berdasarkan hasil perhitungan parameter dasar statistik (nilai Cs dan $\mathrm{Ck}$ ) dengan mencocokan syarat pemilihan distribusi probabilitas pada Tabel 1, distribusi yang bisa dipakai untuk perhitungan curah hujan rancangan adalah $\log$ Pearson III. Hasil perhitungan curah hujan rancangan dengan perode kala ulang 2, 5, 10 tahun dengan metode Log Pearson III sebagai berikut :

- Periode ulang 2 tahun $=83,70 \mathrm{~mm}$

- Periode ulang 5 tahun $=99,14 \mathrm{~mm}$

- Periode ulang 10 tahun $=112,63 \mathrm{~mm}$

\section{c. Uji Kecocokan Distribusi Probabilitas}

- Uji Chi-Kuadrat

Hasil perhitungan chi-kuadrat ditampilkan pada Tabel 2. Dari perhitungan Chi-kuadrat untuk distribusi hujan metode Log Pearson III, didapat nilai Chi-Kuadrat 0,40 , nilai $\mathrm{DK}=2$, dan derajat signifikan $\alpha=$ 
5\%, maka didapat Chi-Kuadrat teoritis 5,991 $>0,40$ perhitungan diterima.

Tabel 2. Perhitungan Chi-Kuadrat

\begin{tabular}{|c|c|c|c|c|}
\hline nilai batas & $\mathbf{O i}$ & $\mathbf{E i}$ & $(\mathbf{O i}-\mathbf{E i})^{\mathbf{2}}$ & $\mathbf{X h}^{\mathbf{2}}$ \\
\hline $\mathrm{X} \leq 1,84$ & 3 & 2.5 & 0.25 & 0.10 \\
\hline $1,84<\mathrm{X} \leq 1,91$ & 2 & 2.5 & 0.25 & 0.10 \\
\hline $1,91<\mathrm{X} \leq 1,98$ & 3 & 2.5 & 0.25 & 0.10 \\
\hline $\mathrm{X} \geq 1,98$ & 2 & 2.5 & 0.25 & 0.10 \\
\hline & 10 & 10 & nilai chi kuadrat $=$ & $\mathbf{0 . 4 0}$ \\
\hline
\end{tabular}

Tabel 3. Perhitungan Uji Smirnov- Kolmogrov

\begin{tabular}{cccccccc}
\hline $\begin{array}{c}\text { Peringkat } \\
(\mathbf{m})\end{array}$ & $\mathbf{x i}$ & $\mathbf{P}=\mathbf{m} /(\mathbf{n}+\mathbf{1})$ & $\begin{array}{c}\mathbf{P}(\mathbf{x}<) \\
\mathbf{1}-\mathbf{P}(\mathbf{x})\end{array}$ & $\begin{array}{c}\mathbf{f}(\mathbf{t})=(\mathbf{x i}- \\
\mathbf{x}) / \mathbf{s}\end{array}$ & $\mathbf{p}^{\prime}(\mathbf{x})$ & $\mathbf{p}^{\prime}(\mathbf{x}<)$ & $\mathbf{D}$ \\
\hline$[\mathbf{1}]$ & {$[\mathbf{2}]$} & {$[3]$} & {$[\mathbf{4}]$} & {$[\mathbf{5}]$} & {$[\mathbf{6}]$} & {$[7]$} & {$[\mathbf{8}]$} \\
\hline 1 & 2.12 & 0.09 & 0.91 & 1.95 & 0.0256 & 0.9744 & 0.0653 \\
\hline 2 & 2.03 & 0.18 & 0.82 & 1.09 & 0.1377 & 0.8623 & 0.0441 \\
\hline 3 & 1.96 & 0.27 & 0.73 & 0.41 & 0.3409 & 0.6591 & -0.0682 \\
\hline 4 & 1.94 & 0.36 & 0.64 & 0.24 & 0.4052 & 0.5948 & -0.0416 \\
\hline 5 & 1.92 & 0.45 & 0.55 & 0.10 & 0.4602 & 0.5398 & -0.0057 \\
\hline 6 & 1.89 & 0.55 & 0.45 & -0.17 & 0.5675 & 0.4325 & -0.0220 \\
\hline 7 & 1.85 & 0.64 & 0.36 & -0.63 & 0.7357 & 0.2643 & -0.0993 \\
\hline 8 & 1.84 & 0.73 & 0.27 & -0.71 & 0.7620 & 0.2380 & -0.0347 \\
\hline 9 & 1.83 & 0.82 & 0.18 & -0.80 & 0.7881 & 0.2119 & 0.0301 \\
\hline 10 & 1.76 & 0.91 & 0.09 & -1.48 & 0.9306 & 0.0694 & -0.0215 \\
\hline$\sum$ & 19.12 & & & & & Dmax $=$ & $\mathbf{0 . 0 6 5 3}$ \\
\hline rata-rata & 1.91 & & & & & &
\end{tabular}

- Uji Smirnov-Kolmogrov

Perhitungan ini ditampilkan pada Tabel 3. Dari perhitungan tabel diatas didapat nilai $\mathrm{D}=0,0653$ pada peringkat $(\mathrm{m})=1$. Derajat kepercayaan $(\mathrm{dk})$ senilai 5\% dan banyaknya data $=10$, jadi didapat nilai Do sebesar 0,41. Nilai $\mathrm{D}<$ Do $(0,0653<0,41)$ maka persamaan distribusi Log Pearson Tipe III tersebut diterima.

\section{d. Perhitungan Intensitas Hujan Rencana}

Perhitungan intensitas hujan rencana bertujuan untuk mendapatkan hasil intensitas hujan menghitung debit rancangan $\left(\mathrm{Q}_{\mathrm{ranc}}\right)$ dengan memperhitungkan waktu konsentrasi aliran $\left(\mathrm{T}_{\mathrm{c}}\right)$. Waktu konsentrasi $\left(\mathrm{T}_{\mathrm{c}}\right)$ dihitung berdasarkan nilai Inlet Time $\left(\mathrm{t}_{0}\right)$ dan nilai Channel flow $\left(\mathrm{t}_{\mathrm{f}}\right)$.

$$
\boldsymbol{T}_{c}=\boldsymbol{t}_{\mathrm{O}}+\boldsymbol{t}_{\boldsymbol{f}}
$$

Hasil perhitungan waktu konsentrasi aliran (Tc) ditampilkan pada Tabel 4. Setelah diketahui besarnya nilai Tc, lalu menghitung intensitas hujan rencana dengan rumus Mononobe. Contoh perhitungan intensitas hhujan rencana pada saluran sekunder Darmo Indah ruas 5-2 :

$I_{10}=42,59 \mathrm{~mm} / \mathrm{jam}$
Perhitungan intenstas hujan rencana ditampilkan pada Tabel 5.

Tabel 4. Perhitungan Nilai Tc

\begin{tabular}{|c|c|c|c|c|c|c|}
\hline \multicolumn{3}{|c|}{ Lokasi } & \multirow{3}{*}{$\frac{\mathrm{t}_{\mathrm{f}}}{\text { (menit) }}$} & \multirow{3}{*}{$\frac{\mathrm{t}_{0}}{\text { (menit) }}$} & \multirow{2}{*}{\multicolumn{2}{|c|}{$\mathrm{T}_{\mathrm{c}}$}} \\
\hline \multirow{2}{*}{$\begin{array}{l}\text { Kode } \\
\text { saluran }\end{array}$} & \multirow{2}{*}{ Nama Saluran } & \multirow{2}{*}{ Ruas } & & & & \\
\hline & & & & & (menit) & (jam) \\
\hline [1] & [2] & [3] & [4] & [5] & {$[6]$} & [7] \\
\hline \multirow{2}{*}{ B } & \multirow{2}{*}{ Darmo Indah } & $1-5$ & 3,99 & 80,54 & 84,53 & 1,41 \\
\hline & & $5-2$ & 6,74 & 45,93 & 52,67 & 0,88 \\
\hline \multirow{2}{*}{$\mathrm{C}$} & \multirow{2}{*}{ Darmo Harapan } & $3-4$ & 8,45 & 41,44 & 49,89 & 0,83 \\
\hline & & $4-5$ & 9,18 & 41,44 & 50,62 & 0,84 \\
\hline \multirow{2}{*}{ D } & \multirow{2}{*}{ Darmo Satelit } & $6-7$ & 13,43 & 63,64 & 77,07 & 1,28 \\
\hline & & $7-8$ & 11,05 & 32,16 & 43,21 & 0,72 \\
\hline \multirow{2}{*}{ E } & \multirow{2}{*}{ Kupang Jaya } & $9-10$ & 14,02 & 133,76 & 147,78 & 2,46 \\
\hline & & $10-11$ & 16,25 & 31,34 & 47,58 & 0,79 \\
\hline \multirow{3}{*}{$\mathrm{F}$} & \multirow{3}{*}{ Simo Mulyo } & $12-13$ & 8,52 & 92,69 & 101,20 & 1,69 \\
\hline & & $13-14$ & 6,47 & 51,22 & 58,98 & 0,98 \\
\hline & & $14-15$ & 3,84 & 51,22 & 55,06 & 0,92 \\
\hline \multirow{2}{*}{ G } & \multirow{2}{*}{ Simo Mulyo Barat } & $14-16$ & 8,20 & 29,33 & 37,53 & 0,63 \\
\hline & & $16-17$ & 6,85 & 41,93 & 48,77 & 0,81 \\
\hline \multirow{2}{*}{$\mathrm{H}$} & \multirow{2}{*}{ Simo Gunung } & $18-19$ & 7,45 & 61,45 & 68,90 & 1,15 \\
\hline & & $19-20$ & 5,80 & 61,45 & 67,25 & 1,12 \\
\hline
\end{tabular}

Tabel 5. Perhitungan Intensitas Hujan Rencana

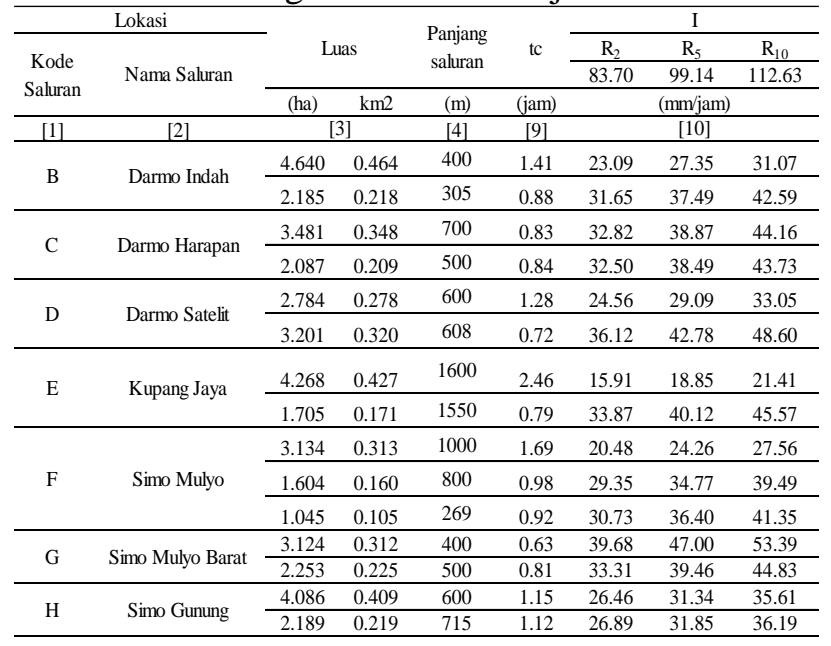

\section{e. Perhitungan Koefisien Pengaliran}

Perhitungan ini untuk mengetahui besarnya nilai koefisien pengaliran ( $\mathrm{C}$ ) berdasarkan luas penggunaan lahan yang ada pada sub DAS yang ditinjau.

Contoh perhitungan nilai C pada tahun 2002 di saluran sekunder Darmo Indah (ruas 1-5)

Luas sub DAS $=463980 \mathrm{~m}^{2}$

Tata guna lahan dan luas tata guna lahannya:

Pemukiman $\quad \mathrm{C}_{1}=0,75$, luas $\mathrm{A}_{1}=450483 \mathrm{~m}^{2}$

Bisnis $\quad \mathrm{C}_{2}=0,95$, luas $\mathrm{A}_{2}=0 \mathrm{~m}^{2}$

Lahan Kosong $\quad \mathrm{C}_{3}=0,2$, luas $\mathrm{A}_{3}=0 \mathrm{~m}^{2}$

RTH $\quad \mathrm{C}_{4}=0,3$, luas $\mathrm{A}_{4}=12708 \mathrm{~m}^{2}$

Industri $C_{5}=0,5$, luas $A_{5}=0 \mathrm{~m}^{2}$

$C_{g a b}=\frac{450483 m^{2} .0 .75+0.0,95+0.0,2+12708 m^{2} .0,3+0.0,5}{0,75+0,95+0,2+0,3+0,5}=0,736$

Hasil perhitungan koefisien pengaliran ditampilkan pada Tabel 6. 
Tabel 6. Koefisien Pengaliran (C) Tahun 2002

\begin{tabular}{|c|c|c|c|c|c|c|c|c|c|c|c|c|c|}
\hline \multirow{3}{*}{$\begin{array}{l}\text { Kode } \\
\text { DAS }\end{array}$} & \multirow{3}{*}{ Namn saluran } & \multirow{3}{*}{ Ruas } & \multirow{2}{*}{$\begin{array}{l}\text { Luas Total } \\
\text { sub DAS } \\
\end{array}$} & \multirow{2}{*}{$\mathrm{Cl}$} & \multicolumn{2}{|c|}{$C_{2}$} & \multicolumn{2}{|c|}{$C_{3}$} & \multicolumn{2}{|l|}{$C 4$} & \multicolumn{2}{|c|}{05} & \multirow{3}{*}{ Cgab } \\
\hline & & & & & Niai & Luas & Nilai & Luas & Nilai L & Luas 1 & Nilai & Luas & \\
\hline & & & $\mathrm{m}^{2}$ & $\mathrm{~m}^{2}$ & C & $\mathrm{m}^{2}$ & C & $\mathrm{m}^{2}$ & c & $\mathrm{m}^{2}$ & C & $\mathrm{m}^{2}$ & \\
\hline \multirow{2}{*}{ B } & \multirow{2}{*}{ Darmo Indah } & 1.5 & 463980 & 451273 & & 0 & & 0 & & 12708 & & 0 & 0.738 \\
\hline & & 5.2 & 218480 & 216370 & & 0 & & 1623 & & 488 & & 0 & 0.745 \\
\hline \multirow{2}{*}{ C } & \multirow{2}{*}{ Darmo Harapan } & 3.4 & 348080 & 332460 & & 0 & & 0 & & 15625 & & 0 & 0.730 \\
\hline & & 4.5 & 208700 & 208133 & & 0 & & 567.5 & & 0 & & 0 & 0.749 \\
\hline \multirow{2}{*}{ D } & \multirow{2}{*}{ Darmo Satelit } & 6.7 & 278370 & 250668 & & 0 & & 6321.75 & & 21780 & & 0 & 0.702 \\
\hline & & 7.8 & 320070 & 320070 & & 0 & & 0 & & 0 & & 0 & 0.750 \\
\hline \multirow{2}{*}{ E } & \multirow{2}{*}{ Kupang Jaya } & $9-10$ & 426790 & 384543 & & 0 & & 617.5 & & 41630 & & 0 & 0.705 \\
\hline & & $10-11$ & 170530 & 158730 & & 0 & & 0 & & 11800 & & 0 & 0.719 \\
\hline \multirow{3}{*}{ F } & \multirow{3}{*}{ Simo Mulyo } & $12 \cdot 13$ & 313400 & 264668 & & 0 & & 8377.5 & & 40558 & & 1648 & 0.680 \\
\hline & & $13 \cdot 14$ & 160400 & 157955 & & 0 & & 2100 & & 350 & & 0 & 0.742 \\
\hline & & 14.15 & 104530 & 104530 & & 0 & & 0 & & 0 & & 2003 & 0.761 \\
\hline \multirow{2}{*}{ G } & \multirow{2}{*}{ Simo Mulyo Barat } & 14.16 & 312407 & 312407 & & 0 & & 0 & & 0 & & 0 & 0.750 \\
\hline & & $16-17$ & 255300 & 225300 & & 0 & & 0 & & 0 & & 0 & 0.750 \\
\hline \multirow{2}{*}{ H } & \multirow{2}{*}{ Simo Gunung } & 18.19 & 408550 & 380200 & & 0 & & 8862.5 & & 19488 & & 0 & 0.717 \\
\hline & & $19-20$ & 218900 & 218900 & & 0.00 & & 0 & & 0 & & 0 & 0.750 \\
\hline
\end{tabular}

Untuk perhitungan koefisien pengaliran (C) tahun 2007, 2009, 2012, 2014 dan tahun 2017 dilakukan dengan cara yang sama.

\section{f. Perhitungan Debit Banjir}

Perhitungan ini untuk mengetahui besarnya debit banjir maksimum yang akan dipakai untuk membandingkan debit banjir dengan dimensi saluran eksisting. Debit banjir dihitung dengan periode kala ulang 2, 5, 10 tahun di masingmasing saluran sekunder berdasarkan intensitas hujan dan koefisien pengaliran.

Contoh perhitungan debit banjir :

Saluran sekunder Darmo Indah ruas 1-5 Tahun 2002

$$
\begin{array}{ll}
\mathrm{C} & =0,736 \\
\mathrm{I}_{5} & =27,35 \mathrm{~mm} / \mathrm{jam} \\
\mathrm{A} & =0,46398 \mathrm{~km}^{2} \\
\mathrm{Q}_{5} \quad=0,278 \times \mathrm{C}_{5} \times \mathrm{A} \\
Q_{5}=0,278 \times 0,736 \times 27,35 \frac{\mathrm{mm}}{j a m} \times 0,46398 \mathrm{~km}^{2} \\
\quad=2,602 \mathrm{~m}^{3} / \text { det }
\end{array}
$$

Perhitungan debit banjir selanjutnya ditampilkan pada Tabel 7.

\subsection{Analisis Tataguna Lahan}

Analisis ini bertujuan untuk mengetahui tingkat kesesuaian lahan dan persebaran serta luas lahan permukiman eksisting berdasarkan kelas kesesuaian lahan permukiman

\section{a. Perhitungan Prosentase Perubahan \\ Tataguna Lahan}

Perhitungan inni untuk mengetahui prosentase pertambahan perubahan lahan yang ada di sistem drainase Gunungsari.

Contoh perhitungan prosentase perubahan lahan :

Saluran sekunder Darmo Satelit ruas 6-7 Tahun 2002 dan 2007
Prosentase pertambahan $=(0,702-0,704) / 0,702 \mathrm{x}$

\begin{tabular}{|c|c|c|c|c|c|c|}
\hline \multirow[t]{2}{*}{ Kode } & \multirow[t]{2}{*}{ Nama Saluran } & \multirow[t]{2}{*}{ Lokasi } & \multirow{2}{*}{$\begin{array}{c}\text { Luas per } \\
\text { segmen } \\
(\mathrm{km} 2)\end{array}$} & Q2 & Q5 & Q10 \\
\hline & & & & $\mathrm{m}^{3} / \mathrm{det}$ & $\mathrm{m}^{3} / \mathrm{det}$ & $\mathrm{m}^{3} / \mathrm{de}$ \\
\hline \multirow{2}{*}{ B } & \multirow{2}{*}{ Darmo Indah } & $1-5$ & 0.46398 & 2.197 & 2.602 & 2.956 \\
\hline & & $5-2$ & 0.21848 & 1.432 & 1.696 & 1.927 \\
\hline \multirow{2}{*}{$\mathrm{C}$} & \multirow{2}{*}{ Darmo Harapan } & $3-4$ & 0.34808 & 2.317 & 2.745 & 3.118 \\
\hline & & $4-5$ & 0.2087 & 1.411 & 1.672 & 1.899 \\
\hline \multirow{2}{*}{ D } & \multirow{2}{*}{ Darmo Satelit } & $6-7$ & 0.27837 & 1.335 & 1.581 & 1.796 \\
\hline & & $7-8$ & 0.32007 & 2.410 & 2.855 & 3.243 \\
\hline \multirow{2}{*}{ E } & \multirow{2}{*}{ Kupang Jaya } & $9-10$ & 0.42679 & 1.331 & 1.577 & 1.792 \\
\hline & & $10-11$ & 0.17053 & 1.154 & 1.367 & 1.553 \\
\hline \multirow{3}{*}{ F } & \multirow{3}{*}{ Simo Mulyo } & $12-13$ & 0.3134 & 1.213 & 1.437 & 1.633 \\
\hline & & 13-14 & 0.1604 & 0.971 & 1.150 & 1.306 \\
\hline & & $14-15$ & 0.10453 & 0.679 & 0.804 & 0.914 \\
\hline \multirow{2}{*}{ G } & \multirow{2}{*}{ Simo Mulyo Barat } & $14-16$ & 0.312407 & 2.584 & 3.061 & 3.478 \\
\hline & & $16-17$ & 0.2253 & 1.565 & 1.854 & 2.106 \\
\hline \multirow{2}{*}{$\mathrm{H}$} & \multirow{2}{*}{ Simo Gunung } & $18-19$ & 0.40855 & 2.154 & 2.551 & 2.898 \\
\hline & & $19-20$ & 0.2189 & 1.227 & 1.454 & 1.652 \\
\hline
\end{tabular}
$100 \%=0,26 \%$

Perhitungan prosentase ini selanjutnya ditampilkan pada Tabel 8.

\begin{tabular}{|c|c|c|c|c|c|}
\hline \multirow[b]{2}{*}{ Kode } & \multirow[b]{2}{*}{ Nama Saluran } & \multirow[b]{2}{*}{ Lokasi } & \multicolumn{2}{|c|}{ Koef.Pengaliran (C) } & \multirow{2}{*}{$\begin{array}{c}\text { Prosentase } \\
\text { Perubahan } \\
(\%)\end{array}$} \\
\hline & & & 2002 & 2007 & \\
\hline \multirow{2}{*}{$\mathrm{B}$} & \multirow{2}{*}{ Darmo Indah } & $1-5$ & 0.738 & 0.738 & 0.00 \\
\hline & & $5-2$ & 0.745 & 0.742 & -0.34 \\
\hline \multirow{2}{*}{$\mathrm{C}$} & \multirow{2}{*}{ Darmo Harapan } & $3-4$ & 0.730 & 0.743 & 1.77 \\
\hline & & $4-5$ & 0.749 & 0.750 & 0.20 \\
\hline \multirow{2}{*}{$\mathrm{D}$} & \multirow{2}{*}{ Darmo Satelit } & $6-7$ & 0.702 & 0.704 & 0.26 \\
\hline & & $7-8$ & 0.750 & 0.750 & 0.00 \\
\hline \multirow{2}{*}{$\mathrm{E}$} & \multirow{2}{*}{ Kupang Jaya } & $9-10$ & 0.705 & 0.693 & -1.74 \\
\hline & & $10-11$ & 0.719 & 0.724 & 0.75 \\
\hline \multirow{3}{*}{$\mathrm{F}$} & \multirow{3}{*}{ Simo Mulyo } & $12-13$ & 0.680 & 0.591 & -15.10 \\
\hline & & 13-14 & 0.742 & 0.717 & -3.29 \\
\hline & & 14-15 & 0.761 & 0.750 & -1.39 \\
\hline \multirow{2}{*}{ G } & \multirow{2}{*}{ Simo Mulyo Barat } & $14-16$ & 0.750 & 0.750 & 0.00 \\
\hline & & $16-17$ & 0.750 & 0.750 & 0.00 \\
\hline \multirow{2}{*}{$\mathrm{H}$} & \multirow{2}{*}{ Simo Gunung } & $18-19$ & 0.717 & 0.717 & 0.05 \\
\hline & & $19-20$ & 0.750 & 0.750 & 0.00 \\
\hline
\end{tabular}

Tabel 7. Perhitungan Debit Banjir Maksimum Tahun 2002

Tabel 8. Perhitungan Prosentase Perubahan Tataguna Lahan

Untuk perhitungan tahun 2009-2012 serta 20142017 pun dilakukan perhitungan yang sama seperti sebelumnya.

\subsection{Analisis Debit Kumulatif}

\section{a. Perhitungan Proyeksi Jumlah Penduduk}

Pada perhitungan ini digunakan selisih pertambahan dan prosentasenya per 10 tahun Berdasarkan data BPS tahun 2010 diketahui bahwa jumlah penduduk pada tiap ruas saluran 
masuk dalam 3 (tiga) wilayah yaitu : Kecamatan Sawahan, Tandes, dan Suko Manunggal untuk menghitung debit domestik di masa mendatang, misal :

- Selisih pertambahan penduduk tahun 1990 dan $2000=30.116-27.239=-2.877$ jiwa

- Prosentase pertambahan $=(30.116-$ $27.239) / 30.116 \times 100 \%=0.10 \%$

Perhitungan selisih penduduk tiap kecamatan ditampilkan pada Tabel 9.

Berdasarkan hasil perhitungan Tabel 9 perhitungan dilanjutkan dengan menggunakan metode proyeksi penduduk untuk mendapatkan nilai $\mathrm{r}$ dan metode yang sesuai dengan kondisi ketiga wilayah akan dicari metode proyeksi penduduk yang paling sesuai untuk ketiga wilayah tersebut :

- Metode Aritmatik

Contoh perhitungan koefisien korelasi untuk metode aritmatik (Wilayah Sawahan)

$$
\begin{aligned}
& r=\frac{n(\Sigma X Y)-(\Sigma X)(\Sigma Y)}{\left\{\left[n\left(\Sigma Y^{2}\right)-(\Sigma Y)^{2}\right]\left[n\left(\Sigma X^{2}\right)-(\Sigma X)^{2}\right]\right\}^{0.5}} \\
& r_{1990-2010}=\frac{20(-7633)-(6)(-5255)}{\left\{\left[20\left(-5255^{2}\right)-(-5255)^{2}\right]\left[20\left(6^{2}\right)-(6)^{2}\right]\right\}^{0.5}}=-0,457
\end{aligned}
$$

Untuk metode least square dan geometrik dilakukan perhitungan dengan rumus yang sama seperti diatas. Hasil dari perhitungan metode aritmatik ditampilkan pada Tabel 10.

Dari hasil perhitungan koefisien korelasi untuk masing-masing metode proyeksi nilai koefisien korelasi yang paling mendekati adalah metode aritmatik. Untuk perhitungan proyeksi penduduk untuk tahun yang direncanakan mengikuti rumus metode aritmatik :

Contoh perhitungan perkiraan jumlah penduduk Kecamatan Sawahan untuk 2011 :

$$
\begin{aligned}
\mathrm{Pn} & =\mathrm{Po}+(\mathrm{r} \times \mathrm{n}) \\
\mathrm{P}_{(2011)} & =\mathrm{P}_{(2010)}(\mathrm{r} \times \mathrm{n}) \\
& =24.861(0,2 \times 1) \\
& =24.861 \text { jiwa }
\end{aligned}
$$

Hasil perhitungan akan disajikan pada Tabel 10 dan Tabel 11.

\section{b. Perhitungan Debit Air Kotor Domestik}

Contoh perhitungan saluran simo gunung :

$\mathrm{P}_{2019}=$ jumlah penduduk $=24.870$ orang

$\mathrm{q}=120$ liter/org/hari (standar debit air baku

\begin{tabular}{|c|c|c|c|c|c|c|c|c|c|c|}
\hline \multirow[b]{2}{*}{ no } & \multirow[b]{2}{*}{ tahun } & \multicolumn{3}{|c|}{$\begin{array}{l}\text { Jumlah Penduduk per } \\
\text { wilayah (jiwa) }\end{array}$} & \multicolumn{3}{|c|}{ selisih penduduk } & \multicolumn{3}{|c|}{ prosentase penduduk } \\
\hline & & sawahan & tandes & $\begin{array}{c}\text { sukom } \\
\text { anung } \\
\text { gal }\end{array}$ & sawahan & tandes & $\begin{array}{c}\text { sukom } \\
\text { anung } \\
\text { gal }\end{array}$ & $\begin{array}{c}\text { sawaha } \\
\mathrm{n}\end{array}$ & tandes & $\begin{array}{c}\text { sukom } \\
\text { anungg } \\
\text { al }\end{array}$ \\
\hline \multirow[t]{2}{*}{1} & 1990 & 30116 & 5230 & 7215 & & & & & & \\
\hline & & & & & -2877 & 3213 & 4433 & -0.10 & 0.38 & 0.38 \\
\hline \multirow[t]{2}{*}{2} & 2000 & 27239 & 8443 & 11648 & & & & & & \\
\hline & & & & & -2378 & 811 & -610 & -0.09 & 0.09 & -0.06 \\
\hline 3 & 2010 & 24861 & 9254 & 11038 & & & & & & \\
\hline \multicolumn{8}{|c|}{ r(rata-rata) prosentase } & -0.1 & 0.2 & 0.2 \\
\hline
\end{tabular}
dari cipta karya untuk perkotaan, $\mathrm{q}=120$ (lt/org/hari)

\begin{tabular}{|c|c|c|c|c|c|c|c|c|c|c|c|c|c|}
\hline \multirow{2}{*}{ tahun } & \multirow{2}{*}{$x$} & \multicolumn{3}{|c|}{$\begin{array}{l}\text { Jumlah penduduk per wilayah } \\
\text { (jiwa) }\end{array}$} & \multicolumn{4}{|c|}{ pertambahan penduduk (y) } & \multicolumn{3}{|l|}{$(x y)$} & \multicolumn{2}{|l|}{$r$} \\
\hline & & sawahan & tandes & $\begin{array}{r}\text { sukoman } \\
\text { unggal }\end{array}$ & $\begin{array}{c}\text { sawaha } \\
n\end{array}$ & tandes & $\begin{array}{r}\text { sukoman } \\
\text { unggal }\end{array}$ & sawahan & tandes & $\begin{array}{l}\text { sukoma } \\
\text { nunggal }\end{array}$ & $\begin{array}{c}\text { sawaha } \\
n\end{array}$ & tandes & $\begin{array}{l}\text { sukoman } \\
\text { unggal }\end{array}$ \\
\hline 1990 & 1 & 30116 & 5230 & 7215 & \multirow[t]{2}{*}{-2877} & \multirow[t]{2}{*}{3213} & \multirow[t]{2}{*}{4433} & -2877 & 3213 & 4433 & & & \\
\hline 2000 & \multirow{2}{*}{2} & 27239 & 8443 & 11648 & & & & 1756 & 102 & טרט & -0.457 & 0.369 & 0.242 \\
\hline 2010 & & 24861 & 9254 & 11038 & --2378 & 811 & -610 & & & & & & \\
\hline$\Sigma$ & 3 & 82216 & 22927 & 29901 & -5255 & 4024 & 3823 & .7633 & 4835 & 3213 & & & \\
\hline
\end{tabular}

Qdom $=\frac{60 \% \times 120 \times 24870}{86400}=0.0077 \mathrm{~m}^{3} / \mathrm{det}$

Perhitungan debit air kotor domestik ditampilkan pada Tabel 12.

\begin{tabular}{|c|c|c|c|c|c|}
\hline \multirow{2}{*}{ TAHUN } & \multirow{2}{*}{$\mathrm{r}$} & \multirow{2}{*}{$\mathrm{n}$} & \multicolumn{3}{|c|}{ JUMAH PENDUDUK (JWA) } \\
\hline & & & SAWAHAN & TANDES & SUKOMANUNGGAL \\
\hline 2010 & \multirow{26}{*}{0.2} & 0 & 24861 & 9254 & 11038 \\
\hline 2011 & & 1 & 24861 & 9254 & 11038 \\
\hline 2012 & & 2 & 24862 & 9255 & 11039 \\
\hline 2013 & & 3 & 24862 & 9255 & 11039 \\
\hline 2014 & & 4 & 24863 & 9256 & 11040 \\
\hline 2015 & & 5 & 24864 & 9257 & 11041 \\
\hline 2016 & & 6 & 24865 & 9258 & 11042 \\
\hline 2017 & & 7 & 24867 & 9260 & 11044 \\
\hline 2018 & & 8 & 24868 & 9261 & 11045 \\
\hline 2019 & & 9 & 24870 & 9263 & 11047 \\
\hline 2020 & & 10 & 24872 & 9265 & 11049 \\
\hline 2021 & & 11 & 24874 & 9267 & 11051 \\
\hline 2022 & & 12 & 24877 & 9270 & 11054 \\
\hline 2023 & & 13 & 24879 & 9272 & 11056 \\
\hline 2024 & & 14 & 24882 & 9275 & 11059 \\
\hline 2025 & & 15 & 24885 & 9278 & 11062 \\
\hline 2026 & & 16 & 24888 & 9281 & 11065 \\
\hline 2027 & & 17 & 24892 & 9285 & 11069 \\
\hline 2028 & & 18 & 24895 & 9288 & 11072 \\
\hline 2029 & & 19 & 24899 & 9292 & 11076 \\
\hline 2030 & & 20 & 24903 & 9296 & 11080 \\
\hline 2031 & & 21 & 24907 & 9300 & 11084 \\
\hline 2032 & & 22 & 24912 & 9305 & 11089 \\
\hline 2033 & & 23 & 24916 & 9309 & 11093 \\
\hline 2034 & & 24 & 24921 & 9314 & 11098 \\
\hline 2035 & & 25 & 24926 & 9319 & 11103 \\
\hline
\end{tabular}

Tabel 9. Perhitungan Selisih Pertambahan

Tabel 10. Perhitungan Metode Secara Aritmatik

Tabel 11. Perhitungan Proyeksi Jumlah Penduduk Metode Aritmatik

Keterangan :

r (nilai korelasi) yang dipakai sama untuk tahun 2010 sampai dengan tahun 2035 sesuai dengan nilai yang didapat pada perhitungan sebelumnya. 
Berdasarkan hasil perhitungan debit air kotor domestik pada Tabel 12, dilakukan perhitungan debit air kumulatif dimana debit air melintasi saluran drainase akibat debit banjir rancangan periode ulang 2, 5, 10 tahun ditambah dengan air kotor.

Contoh perhitungan debit air kumulatif (kala ulang 2 tahun) pada Darmo Harapan (ruas 3-4) : $Q_{\text {air kumulatif }}=2,382 \mathrm{~m}^{3} / \mathrm{det}+0,0077 \mathrm{~m}^{3} / \mathrm{det}$ $=2,382 \mathrm{~m}^{3} / \mathrm{det}$

Hasil perhitungan ditampilkan pada Tabel 13.

\section{Analisis Hidrolika (Analisis Kapasitas Saluran)}

Analisis kapasitas bertujuan untuk mengetahui kemampuan saluran menampung debit banjir yang terjadi dengan menggunakan analisis hidrolika sederhana.

\section{a. Perhitungan Kapasitas Saluran Eksisting}

Contoh kontrol kapasitas saluran Darmo Indah untuk kala ulang 5 tahun adalah sebagai berikut :

Darmo Indah (ruas 1-5)

Data dimensi saluran :

$\begin{array}{lll}\text { Lebar dasar saluran } & \text { (b) } & =3,90 \mathrm{~m} \\ \text { Kedalaman saluran } & (\mathrm{H}) & =1,6 \mathrm{~m} \\ \text { Kemiringan talud } & (\mathrm{m}) & =0,45 \\ \text { Kekasaran manning } & (\mathrm{n}) & =0,030 \\ \text { Panjang saluran } & \left(\mathrm{L}_{\text {sal. }}\right) & =400 \mathrm{~m}\end{array}$

Kemiringan saluran $\left(\mathrm{S}_{0}\right)$

$=0,0027$

Bentuk saluran

$=$ Trapesium

Perhitungan kapasitas eksisting saluran ditampilkan pada Tabel 14.

Tabel 12. Perhitungan Debit Air Domestik Berbagai Kala Ulang

\begin{tabular}{|c|c|c|c|c|c|c|c|c|}
\hline \multirow{2}{*}{$\begin{array}{l}\text { Koda } \\
\text { DAS }\end{array}$} & \multirow{2}{*}{$\begin{array}{l}\text { Nama } \\
\text { Saluran }\end{array}$} & \multirow{2}{*}{ Lokasi } & \multicolumn{3}{|c|}{ Jumlah Penduduk } & \multicolumn{3}{|c|}{ Qdom ( $\mathrm{m}^{3} /$ detik $)$} \\
\hline & & & th 2019 & th 2024 & th 2034 & $\begin{array}{c}2 \\
\text { tahun }\end{array}$ & $\begin{array}{c}5 \\
\text { tahun } \\
\end{array}$ & $\begin{array}{c}10 \\
\text { tahun }\end{array}$ \\
\hline B & $\begin{array}{l}\text { Darmo } \\
\text { Indah }\end{array}$ & $\begin{array}{l}1-5 \\
5-2\end{array}$ & \multirow[b]{2}{*}{9263} & \multirow[b]{2}{*}{9275} & \multirow[b]{2}{*}{9314} & \multirow[b]{2}{*}{0.0077} & \multirow[b]{2}{*}{0.0077} & \multirow[b]{2}{*}{0.0078} \\
\hline $\mathrm{C}$ & $\begin{array}{c}\text { Darmo } \\
\text { Harapan }\end{array}$ & $\begin{array}{l}3-4 \\
4-5\end{array}$ & & & & & & \\
\hline D & $\begin{array}{l}\text { Darmo } \\
\text { Satelit }\end{array}$ & $\begin{array}{l}6-7 \\
7-8\end{array}$ & \multirow{4}{*}{11047} & \multirow{4}{*}{11059} & \multirow{4}{*}{11098} & \multirow{4}{*}{0.0092} & \multirow{4}{*}{0.0092} & \multirow{4}{*}{0.0092} \\
\hline E & $\underset{\text { Jaya }}{\text { Kupang }}$ & \begin{tabular}{|l|}
$9-10$ \\
$10-11$ \\
\end{tabular} & & & & & & \\
\hline $\mathrm{F}$ & Simo Mulyo & $\begin{array}{l}12-13 \\
13-14 \\
14-15 \\
\end{array}$ & & & & & & \\
\hline $\mathrm{G}$ & $\begin{array}{c}\text { Simo Mulyo } \\
\text { Barat }\end{array}$ & \begin{tabular}{|l|}
$14-16$ \\
$16-17$ \\
\end{tabular} & & & & & & \\
\hline $\mathrm{H}$ & $\begin{array}{c}\text { Simo } \\
\text { Gunung }\end{array}$ & $\begin{array}{l}18-19 \\
19-20 \\
\end{array}$ & 24870 & 24882 & 24921 & 0.0207 & 0.0207 & 0.0208 \\
\hline
\end{tabular}

Tabel 13. Perhitungan Debit Air Kumulatif

\begin{tabular}{|c|c|c|c|c|c|c|c|c|c|c|c|}
\hline \multirow{2}{*}{$\begin{array}{l}\text { Roda } \\
\text { DAS }\end{array}$} & \multirow{2}{*}{$\begin{array}{l}\text { Vers } \\
\text { Salrem }\end{array}$} & \multirow{2}{*}{ Lolasi } & \multicolumn{3}{|c|}{ Qarthjes } & \multicolumn{3}{|c|}{ Qdon $\left(\mathbb{m}^{5}\right.$ detili $)$} & \multicolumn{3}{|c|}{ Qair ( $m^{3}$ deelk) } \\
\hline & & & Tahme & Stahen & 10tahus & $\begin{array}{c}2 \\
\text { tahn }\end{array}$ & $\begin{array}{c}5 \\
\text { tabn } \\
\end{array}$ & $\begin{array}{c}10 \\
\text { tahm }\end{array}$ & Itatem & Stàm & 10tahn \\
\hline \multirow{2}{*}{ B } & \multirow{2}{*}{$\begin{array}{l}\text { Damo } \\
\text { Inlah }\end{array}$} & $1-5$ & 2.234 & 2.645 & 3.006 & \multirow{4}{*}{0.00077} & \multirow{4}{*}{ a.0.7n } & \multirow{4}{*}{0.0073} & 224 & 2.654 & 3.014 \\
\hline & & $5-2$ & 1.434 & L.698 & 1929 & & & & 1.434 & 1.706 & 1.937 \\
\hline \multirow{2}{*}{ c } & \multirow{2}{*}{$\begin{array}{l}\text { Damen } \\
\text { Harg̣en }\end{array}$} & 34 & 2.332 & 2.821 & 3205 & & & & 2382 & 2.821 & $3.2 \mathrm{w5}$ \\
\hline & & 45 & 1.414 & 1.675 & 1903 & & & & 1.414 & 1.675 & 1.983 \\
\hline \multirow{2}{*}{ D } & \multirow{2}{*}{$\begin{array}{l}\text { Dempo } \\
\text { Satelit }\end{array}$} & $6-7$ & 1.46 & 1.713 & 1946 & \multirow{9}{*}{-0.0092} & \multirow{9}{*}{0.0992} & \multirow{7}{*}{0.0092} & 1.455 & 1.722 & 1.955 \\
\hline & & 18 & 2.410 & 2.855 & 3243 & & & & 2.419 & 2.864 & 3.252 \\
\hline \multirow{2}{*}{ E } & \multirow{2}{*}{$\begin{array}{l}\text { Kryeng } \\
\text { lezz }\end{array}$} & $9-16$ & 1.423 & 1.685 & 1915 & & & & 1.432 & 1.695 & 1.924 \\
\hline & & 10.11 & 1.219 & L.444 & 1.641 & & & & 1.228 & 1.453 & 1.650 \\
\hline \multirow{3}{*}{$F$} & \multirow{3}{*}{ Sim 3roiyo } & $12-13$ & 1.265 & 1.499 & 1.703 & & & & 1.274 & 1.508 & 1712 \\
\hline & & $13-14$ & 0.956 & 1.132 & 1286 & & & & 0965 & 1.141 & 1.296 \\
\hline & & $14-15$ & 0.670 & 0.793 & $0.90 \mathrm{I}$ & & & & 0.679 & 0.002 & 0.910 \\
\hline \multirow[t]{2}{*}{ G } & \multirow{2}{*}{$\begin{array}{l}\text { Sims Mrlyo } \\
\text { Bust }\end{array}$} & $14-16$ & 2534 & 3.861 & 3.478 & & & & 2.594 & 3.000 & 3.487 \\
\hline & & $16-1 ?$ & 1.565 & 1.854 & 2.106 & & & & 1.574 & 1.863 & 2.115 \\
\hline \multirow{2}{*}{$\mathrm{H}$} & \multirow{2}{*}{$\begin{array}{l}\text { Smes } \\
\text { Gung }\end{array}$} & 18:-19 & 2218 & 2.627 & 2985 & \multirow{2}{*}{-0.0000} & \multirow{2}{*}{$0020 ?$} & \multirow{2}{*}{0.0003} & 2.239 & 2.648 & 3.006 \\
\hline & & $19-20$ & 1.227 & L.454 & 1.652 & & & & 1.245 & 1.475 & 1.672 \\
\hline
\end{tabular}

Setelah diketahui debit banjir rencana $\left(\mathrm{Q}_{\text {renc }}\right)$, debit domestik $\left(\mathrm{Q}_{\mathrm{dom}}\right)$, debit air kumulatif $\left(\mathrm{Q}_{\mathrm{ak}}\right)$ dan kapasitas saluran ( $\left.\mathrm{Q}_{\mathrm{kap}}\right)$ selanjutnya dilakukan perbandingan antara keempat debit tersebut. Hal ini untuk mengetahui saluran mana saja yang tidak mampu menampung debit banjir pada periode kala ulang 10 tahun. Perbandingan tersebut akan ditampilkan pada Tabel 15. Saluran sekunder yang masih terjadi banjir perlu dilakukan dengan megganti material saluran dengan penggunaan box culvert, melakukan pemeliharaan dan membersihkan sampah untuk upaya penanggulangan banjir pada saluran sistem Gunungsari.

Berdasarkan hasil perhitungan perbandingan debit banjir maksimum pada Tabel 15, saluran sekunder yang tidak mampu menampung $\mathrm{Q}_{\mathrm{ak}}$ pada saluran adalah : $\mathrm{Q}_{\text {kap }}$ Saluran Darmo Indah (ruas 5-2) $=2,49 \mathrm{~m}^{3} / \mathrm{det}<$ $\mathrm{Q}_{\mathrm{ak}}$ (debit air kumulatif) $=4,951 \mathrm{~m}^{3} /$ det, $\mathrm{Q}_{\text {kap }}$ Saluran Darmo Harapan (ruas 4-5) $=2,90 \mathrm{~m}^{3} / \mathrm{det}$ $<\mathrm{Q}_{\mathrm{ak}}=5,108 \mathrm{~m}^{3} / \mathrm{det}$, $\mathrm{Q}_{\mathrm{kap}}$ Saluran Darmo Satelit $\left(\right.$ ruas 7-8) $=4,08 \mathrm{~m}^{3} / \mathrm{det}<\mathrm{Q}_{\mathrm{ak}}=5,208 \mathrm{~m}^{3} / \mathrm{det}$, dan $Q_{\text {kap }}$ Saluran Simo Gunung (ruas 18-19) = $1,31 \mathrm{~m}^{3} / \mathrm{det}<\mathrm{Q}_{\mathrm{ak}}=3,006 \mathrm{~m}^{3} / \mathrm{det}$. Tetapi pada saluran darmo indah (ruas 5-2) dan darmo satelit (ruas 7-8) tidak bisa menggunakan box culvert ini karena area sekitar saluran adalah area pemukiman padat penduduk. 
Tabel 14. Perhitungan Kapasitas Saluran Eksisting

\begin{tabular}{|c|c|c|c|c|c|c|c|c|c|c|c|}
\hline \multicolumn{2}{|l|}{ Lobasi } & \multicolumn{3}{|c|}{ Eksisting Sahran } & \multirow[b]{2}{*}{$\begin{array}{l}\text { P } \\
\text { (II) }\end{array}$} & \multirow[b]{2}{*}{$\underset{\text { (m) }}{R}$} & \multirow[b]{2}{*}{$a$} & \multirow[b]{2}{*}{$\mathrm{S}_{0}$} & \multirow[b]{2}{*}{$\begin{array}{c}\mathrm{A} \\
\left(\mathrm{m}^{2}\right)\end{array}$} & \multirow[b]{2}{*}{$\underset{\text { (midts) }}{V}$} & \multirow[b]{2}{*}{$\frac{\mathrm{O}^{\mathrm{n}}}{\left(\mathrm{m}^{3} / \mathrm{C}\right.}$} \\
\hline $\begin{array}{l}\text { Nema } \\
\text { Sahran }\end{array}$ & Ruas & $\begin{array}{c}b \\
b\end{array}$ & H & II & & & & & & & \\
\hline \multirow{2}{*}{ Damns Intah } & $1-5$ & 3.99 & 160 & 0.45 & 7.79 & 095 & 0.030 & 0.0027 & 7.39 & 167 & 12 \\
\hline & $5-2$ & 3.00 & 110 & 0 & 520 & 0.63 & 0.090 & 0.0009 & 3.30 & 0.75 & 24 \\
\hline Damno & $3-4$ & 5.00 & 090 & 0.45 & 7.45 & 0.65 & 0.095 & 0.0030 & 4.86 & 138 & 6.7 \\
\hline Harapan & 4.5 & 239 & 120 & 03 & 4.91 & 0.65 & 0.030 & 0.0013 & 3.19 & 0.91 & 2.9 \\
\hline \multirow{2}{*}{ Darmo Satelit } & $6-7$ & 420 & 098 & 0.45 & 6.75 & 067 & 0.095 & $0,00 \%$ & 4.55 & 0.74 & 3.3 \\
\hline & $7-8$ & 3.90 & 114 & 0 & 6.18 & 0.72 & 0.030 & 0.0012 & 4.55 & 092 & 4.0 \\
\hline \multirow{3}{*}{ Kryeng Irya } & $9-10$ & 6.95 & 109 & 05 & 10.04 & 0.80 & 0.095 & 0.0044 & 8.01 & 190 & 15: \\
\hline & $10-11$ & 3.40 & 139 & 0 & 618 & 0.76 & 0.090 & 0.0033 & 4.73 & 159 & 2.5 \\
\hline & $12-13$ & 7.00 & 105 & 05 & 10.17 & 0.78 & 0.025 & 0.0034 & 7.90 & 196 & 15. \\
\hline \multirow[t]{2}{*}{ Smo kndyo } & 13-14 & 4.70 & 160 & 0.4 & $\$ 51$ & 100 & 0.030 & 0.0026 & 3.54 & 172 & 14. \\
\hline & $14-15$ & 4.00 & 210 & 0 & 8.20 & 1.02 & 0.099 & 0.0012 & 8.40 & 117 & 9.8 \\
\hline \multirow{2}{*}{$\begin{array}{l}\text { Simo datyo } \\
\text { Baret }\end{array}$} & $14-16$ & 6.00 & 180 & 0.6 & 11.20 & 114 & 0.099 & 0.0065 & 12.74 & 0.81 & 103 \\
\hline & $16-17$ & 6.80 & 190 & 0 & 10.60 & 122 & 0.099 & 0.0010 & 12.92 & 122 & 15. \\
\hline \multirow{2}{*}{ Simo Gumng } & $18-19$ & 1.70 & 050 & 05 & 3.02 & 0.32 & 0.025 & 0.0051 & 6.98 & 134 & 1.3 \\
\hline & $19-20$ & 4.50 & 200 & 0 & 8.50 & 105 & 0.030 & 0.0035 & 9.00 & 205 & 18. \\
\hline
\end{tabular}

Tabel 15. Perhitungan Kapasitas Saluran Eksisting dan Debit Banjir Rencana

\begin{tabular}{|c|c|c|c|c|c|c|c|}
\hline $\begin{array}{l}\text { Nama } \\
\text { Saluran }\end{array}$ & $\begin{array}{l}\text { Titik } \\
\text { Saluran }\end{array}$ & $\begin{array}{l}\text { Qrenc } \\
10 \text { th } \\
\text { (m3/det) }\end{array}$ & $\begin{array}{l}\text { Qdom } \\
10 \text { th } \\
\left(\mathrm{m}^{3} / \mathrm{det}\right)\end{array}$ & \multicolumn{2}{|c|}{$\begin{array}{l}\text { Qak 10 th } \\
\text { (m³/det) }\end{array}$} & $\begin{array}{c}\text { Kapasitas } \\
\text { saluran } \\
\text { (m3/det) }\end{array}$ & Statu \\
\hline \multirow{2}{*}{ Darmo Indah } & $1-5$ & 3.006 & \multirow{4}{*}{0.0078} & 3.014 & \multirow{3}{*}{4.951} & 12.37 & amal \\
\hline & $5-2$ & 1.929 & & 1.937 & & 2.49 & meluk \\
\hline Darmo & 34 & 3.205 & & 3.205 & & 6.72 & amal \\
\hline Harapan & $4-5$ & 1.903 & & 1.903 & 5.108 & 2.90 & $\overline{\text { melut }}$ \\
\hline Darmo & $6-7$ & 1.946 & \multirow{9}{*}{0.0092} & 1.955 & & 3.39 & amal \\
\hline Satelit & $7-8$ & 3.243 & & 3.252 & 5.208 & 4.08 & $\overline{\text { melut }}$ \\
\hline \multirow{2}{*}{ Kupang Jaya } & $9-10$ & 1.915 & & 1.924 & & 15.22 & ama \\
\hline & $10-11$ & 1.641 & & 1.650 & 3.574 & 7.52 & amal \\
\hline \multirow{3}{*}{ Simo Mulyo } & $12-13$ & 1.703 & & 1.712 & & 15.47 & amal \\
\hline & $13-14$ & 1.286 & & 1.296 & 3.007 & 14.67 & amal \\
\hline & $14-15$ & 0.901 & & 0.910 & 3.918 & 9.80 & amal \\
\hline \multirow{2}{*}{$\begin{array}{c}\text { Simo Mulyo } \\
\text { Barat }\end{array}$} & $14-16$ & 3.478 & & 3.487 & & 10.36 & amal \\
\hline & $16-17$ & 2.106 & & 2.115 & 5.602 & 15.72 & ama \\
\hline Simo & $18-19$ & 2.985 & \multirow{2}{*}{0.0208} & 3.006 & & 1.31 & melut \\
\hline Gunung & $19-20$ & 1.652 & & 1.672 & 4.678 & 18.49 & ama \\
\hline
\end{tabular}

\section{KESIMPULAN DAN SARAN}

Dari hasil perhitungan ini dapat disimpulkan bahwa :

1. Perubahan tataguna lahan mempengaruhi debit banjir di Surabaya Barat. Didapat perbandingan nilai ( $\mathrm{C}$ ) rata-rata dari tahun 2002 senilai 0,732 , lalu tahun 2007 senilai 0,725 dan pada tahun 2017 nilai c rata-rata senilai 0,747. Dengan luas daerah DAS Gunungsari sebesar 41,7849 Ha.

2. Peningkatan koefisien akibat perubahan tata guna lahan membuat debit banjir yang terjadi di Kota Surabaya Barat meningkatan. Pada periode ulang 2, 5, 10 tahun saluran Darmo Indah (ruas 5-2) prosentase meningkat menjadi 0,94\%, saluran Darmo Harapan (ruas 4-5) masih sama dengan prosentase sebesar $0,20 \%$, saluran Darmo Satelit (ruas 7-8) tidak ada perubahan debit dan saluran Simo Gunung pada periode 2 tahun mengalami penurunan sebesar $-2,91 \%$. Tetapi pada periode ulang 5 tahun meningkat sebesar 3,00\%. Namun pada periode ulang 10 tahun saluran Simo Gunung prosentase menurun sebesar $-3.32 \%$.

3. Kapasitas saluran drainase eksisting di Surabaya Barat yang masih tidak mampu menampung beban limpasan periode ulang 10 tahun antara lain :Qkap Saluran Darmo Indah (ruas 5-2) $=2,49 \mathrm{~m} 3 / \mathrm{det}<$ Qak (debit air kumulatif) $=4,951 \mathrm{~m} 3 /$ det, Qkap Saluran Darmo Harapan (ruas 4-5) = 2,90 m3/det < Qak = 5,108 m3/det, Qkap Saluran Darmo Satelit (ruas 7-8) = 4,08 m3/det < Qak = 5,208 m3/det, dan Qkap Saluran Simo Gunung (ruas $18-19)=1,31 \mathrm{~m} 3 /$ det $<$ Qak $=3,006 \mathrm{~m} 3 /$ det .

4. Solusi untuk upaya penanggulangan perubahan tataguna lahan yang terjadi di kota Surabaya adalah dengan melarang pembangunan diatas saluran sebagai lahan bisnis atau pemukiman, melaksanakan pemeliharaan dan perawatan terhadap saluran yang mengalami keretakan, ditumbuhi tanaman pengganggu, sampah buangan penduduk dan material seperti pasir dan batu kerikil di sekitar saluran secara berkala, dan mengganti saluran yang ada dengan penggunaan teknologi saluran beton pracetak atau box culvert alasannya selain biayanya murah, konstruksinya pun mudah tidak membutuhkan waktu yang lama. Tetapi pada saluran darmo indah (ruas 5-2) dan darmo satelit (ruas 7-8) tidak bisa menggunakan box culvert ini karena area sekitar saluran adalah area pemukiman padat penduduk.

\section{DAFTAR PUSTAKA}

[1] Nainggolan, Julius; Yohanna Lilis H.; SIgit Sutikno, Analisis DAmpak Perubahan Tata Guna Lahan DAS Siak Bagian Hulu Terhadap Debit Banjir, Jom FTEKNIK Vol.2, No. 2, 2015.

[2] Saleh, Chairil, Kajian Penanggulangan Limpasan Permukaan Dengan Menggunakan Sumur Resapan (Studi Kasus di Daerah Perumnas Made Kabupaten Lamongan), Media Teknik Sipil, Vol.9, N0.2, 2011.

[3] Soewarno. 1995. Aplikasi Metode Statistik Untuk Analisa Data Hidrologi. Bandung: Nova.

[4]Triatmodjo, B. 2010. Hidrologi Terapan. Yogyakarta: Beta Offset 